\title{
Current Developments and Challenge of Implantable Bone Conduction Hearing Aids
}

\author{
Saea $\mathrm{Kim}^{1}$ and Woojae $\operatorname{Han}^{2}$ \\ ${ }^{1}$ Department of Speech Pathology and Audiology, Graduate School, Hallym University, Chuncheon; and \\ ${ }^{2}$ Division of Speech Pathology and Audiology, Research Institute of Audiology and Speech Pathology, College of Natural Sciences, \\ Hallym University, Chuncheon, Korea
}

\section{이식형 골도 보청기의 발전과 앞으로의 발전}

김 세 아 ${ }^{1}$ 한 우 재 ${ }^{2}$

한림대학교 일반대학원 언어병리청각학과, ${ }^{1}$ 한림대학교 자연과학대학 언어청각학부, 청각언어연구소 ${ }^{2}$

\author{
Received September 8, 2017 \\ Revised October 18, 2017 \\ Accepted November 6, 2017 \\ Address for correspondence \\ Woojae $\mathrm{Han}, \mathrm{PhD}$ \\ Division of Speech Pathology and \\ Audiology, Hallym University, \\ 1 Hallimdaehak-gil, \\ Chuncheon 24252, Korea \\ Tel $+82-33-248-2216$ \\ Fax $+82-33-256-3420$ \\ E-mailwoojaehan@hallym.ac.kr
}

It is acknowledged that implantable bone conduction hearing aids such as a bone anchored hearing aid provide benefit and satisfaction to patients with unilateral hearing loss in terms of sound localization and speech perception under noise circumstances. This review paper introduces current models of the implantable bone conduction hearing aids, their candidacy, brief surgical procedures, and general audiological examinations. A table summary was used for nine published research papers which have very similar results by three points, i.e., no change in ability of sound localization, better performance of Hearing-In-Noise Test, and improved satisfaction of sound quality using questionnaires after the implantation. Unfortunately, systematic fitting strategy for users of the implantable bone conduction hearing aids has not been either studied or developed yet. Futhermore, there is no scientific based approach of reason why the implantation has no benefit in sound localization but still provides better performance for speech perception in noise. In conclusion, specific and effective fitting strategy of the current implantable bone conduction hearing aids should be developed and also support effect of the implantation with sensitivity and specificity for both clinicians and patients while accompanying their advanced technology.

Korean J Otorhinolaryngol-Head Neck Surg 2018;61(2):67-75

Key Words Bone anchored hearing aids · Bone conduction - Sound localization · Speech recognition $\cdot$ Questionnaires.

\section{서 론}

1935년 철 입자로 고막을 진동시키는 실험을 계기로1) 1950 년대 후반에 들어서면서 고막에 교차형 자기장을 장치하는 연구가 본격적으로 진행되었다. ${ }^{2)}$ 이러한 초기 시도들은 추후 이식형 골도 보청기의 임상적 가능성을 평가하는 연구의 근 간이 되었다. 실험실에서만 진행되던 연구들이 서서히 임상 현

This is an Open Access article distributed under the terms of the Creative Commons Attribution Non-Commercial License (http://creativecommons.org/licenses/by-nc/4.0) which permits unrestricted non-commercial use, distribution, and reproduction in any medium, provided the original work is properly cited.
장으로 이동하면서 1977년 '골전도 직접 방식’을 성공시켰고, 1981년 측두엽에 보청기를 직접 부착하여 약 $15 \mathrm{~dB}$ 의 청각 적 이득을 제공하였다. ${ }^{3)}$ 이러한 골전도 자극전달 방식은 이 식형 골도 보청기가 와우에 근접할수록 효과적으로 소리를 전달할 것이라는 논리에 근거하여 1995년 이식형 골도 보청 기를 유양돌기의 약 $55 \mathrm{~mm}$ 깊이에 삽입시켰다. ${ }^{3)} 2001$ 년 미국 식품의약청에서는 이식형 골도 보청기가 주변 배경 소음 속 에서 음원을 인지하거나 음원의 위치를 판단하는 데 임상적 으로 큰 효과가 있음을 확인하여 양측 이식술을 승인하였고, ${ }^{4}$ 이듬해인 2002년 9월 편측성난청(single sided deafness, 
$\mathrm{SSD}$ ) 환자를 위한 골도 보청기 이식을 승인하였다. ${ }^{5)}$ 국내에서 도 2005년 첫 이식술을 시작으로 꾸준히 수술 건수가 늘고 있 다. 그러나 이식된 골도 보청기는 유양돌기부의 지속적인 압 박으로 인한 부착부의 통증, 피부 자극, 두통 등의 불편함을 유발시키고 부착부의 불안정 등의 단점을 자주 발생시켰다. ${ }^{6}$ 이에 대한 하나의 해결 방안으로 최근 이식형 골전도 보청기 를 피하형으로 전환하였다.

이식형 골도 보청기는 기도 전도 보청기와 비교 시, 외이의 부차적인 염증 없이 착용이 편안하고 사용이 간편하며 미적 으로도 우수하다. ${ }^{6}$ 또한, 이식형 골도 보청기는 피부나 연부조 직을 거치지 않고 직접 두개골을 자극하여 소리를 전달하기 때문에 비교적 편안하게 소리를 들을 수 있는 장점이 크다. 즉, 송화기를 통해 들어온 소리를 환자의 청력 역치에 맞게 적절히 증폭시킨 후 중이 내에 이식된 진동 트랜스듀서에 신 호를 전달하여 진동 신호를 발생시킴으로써 사용자가 소리 를 인식하도록 한다. ${ }^{8)}$ 따라서 골도 전도에 의한 음 자극은 중 이를 거치지 않고 달팽이관으로 직접 전달되기 때문에, 이식 형 골도 보청기 시술에 의한 청력 회복은 환자의 와우 기능에 따라 크게 좌우된다.9) 달리 말해 소리의 전달 과정에서 외이 도 경로를 거치지 않기 때문에 음향 피드백 현상이 없고, 지 나친 증폭을 사용하지 않아 소리 왜곡도 적다. 또한 소리가 가 진 주파수 특성을 비교적 그대로 내이에 전달하기 때문에 어 음 명료도 역시 기도 전도 보청기보다 더 우수하다.

이식형 골도 보청기는 두개골에 직접 기기를 부착하여 청 력 개선을 도모하는 청각재활 수단으로써, 환자의 고막 및 이소골의 존재 여부와 상관없이 청력 개선을 기대할 수 있다 는 점과 기존 골도 보청기의 단점으로 지적되어 왔던 피부 및 피하 연부조직으로 인한 감쇄량을 다소 감소시킬 수 있다 는 점에서 만성 중이염 환자나 외이 기형으로 인해 기도 전도 보청기 착용이 어려운 환자들에게 유용한 대안으로 여겨져 왔다.10) 또한 편측성 난청 환자에게 이식형 골도 보청기는 난 청이 있는 귀 쪽에서 소리 자극을 받아 두개골 진동을 통한 골전도 방식으로, 달팽이관의 기능이 온전한 반대측 귀로 전 달해주는 contralateral routing of signal(CROS)의 역할로 인 해 두영효과(head shadow effect)를 최소화하는 것으로 잘 알려져 있다. ${ }^{6}$ 이러한 우수한 장점에도 불구하고, 이식형 골도 보청기에 대한 자세한 정보가 부재하고, 수술적 기대에 대하 여 잘못 이해하고 있거나 청각적 측면에서 여전히 생소한 부 분이 있다. 따라서 본 종설에서는 현재 시술되고 있는 이식형 골도 보청기에 대해 구체적으로 소개하고, 이식 적합 대상자 및 수술 절차를 포함하여 일반적으로 수술 전/후로 시행되 는 청각 검사법, 골도 보청기 조절 및 착용으로 인한 청각적 이득에 대하여 정리하고, 나아가 앞으로의 임상적 연구 방향
에 대하여 논의하고자 한다.

\section{Current Tendency}

\section{Manufacturers and models}

Cochlear $^{\mathrm{TM}}$, MED-EL, Sophono, Oticon의 제조사에서 출시된 이식형 골도 보청기는 크게 외부장치와 내부장치로 구분한다(Table 1).

먼저 Cochlear ${ }^{\mathrm{TM}}$ (Sydney, Australia)의 최신 외부장치는 2015년에 출시된 Baha ${ }^{\circledR} 5$ Sound Processor이다. 이 외부장치 는 최대 17 개의 채널과 4 개의 프로그램을 사용할 수 있으며, 고도의 난청 환자를 위해 출력이 더 강한 $\mathrm{Baha}^{\circledR} 5$ Power Sound Processer와 Baha ${ }^{\circledR} 5$ Superpower Sound Processor 로 교환 가능하다. 내부장치는 Baha ${ }^{\circledR}$ Attract System과 Baha ${ }^{\circledR}$ Connect System으로 나뉘어져 있다. Baha ${ }^{\circledR}$ Attract System 은 자석을 내부에 삽입하여 외부장치와 간접적으로 연결하 는 방식이라면, Baha ${ }^{\circledR}$ Connect System은 내부에 titanium 나사를 삽입하여 외부장치와 직접적으로 연결하는 방식이다. 삽입되는 자석과 titanium 나사의 종류는 두 가지가 있으며 삽입된 자석은 자가공명영상법(magnetic resonance imaging, MRI) 검사 시 1.5 tesla까지 영향을 받지 않는다.

MED-EL(Innsbruck, Austria)의 최신 이식형 골도 보청기 는 2014년 출시된 SAMBA Audio Processor이다. SAMBA Audio Processor는 총 16 개의 채널과 5개의 프로그램을 포함 하고 있다. 내부장치인 BCI 601은 Cochlear ${ }^{\mathrm{TM}}$ 의 Baha ${ }^{\circledR}$ Attract System과 동일하게 attachment 타입이며 1.5 tesla까지 MRI 검사 시 영향을 받지 않는다.

Sophono(Boulder, CO, USA)의 최신 외부장치는 2014년에 출시된 Sophono ${ }^{\circledR}$ Alpha $2 \mathrm{MPO}^{\mathrm{TM}}$ Processor로, 8 개의 채널 과 4개의 프로그램을 사용할 수 있다. 내부장치는 자석을 내 부에 삽입하는 방식인 Sophono ${ }^{\circledR}$ Magnet Implant이며 약 $2.6 \mathrm{~mm}$ 크기로, 다른 제품과 비교 시 MRI 검사에 가장 덜 영향을 받는다(최대 3 tesla까지).

Oticon(Copenhagen, Denmark)에서 2009년에 출시된 이 식형 골도 보청기는 Ponto 3이라 불리는 외부장치가 대표적 이고, 난청의 정도가 심한 환자들을 위한 Ponto 3 Power와 Ponto 3 Superpower가 있다. Ponto 3는 15개의 채널과 4개 의 프로그램을 사용할 수 있고, 함께 사용되는 내부장치는 Photo BHX implant이다. 주로 titanium을 이식하여 외부장 치와 연결하는 방식을 사용한다.

제조사들의 외부장치를 비교하였을 때, 타 제조사의 외부 장치는 프로그램 수가 4개인 반면 MED-EL의 Samba Audio Processor는 프로그램 수가 5 개로 가장 많다. Cochlear ${ }^{\mathrm{TM}}$ 의 
Implantable Bone Conduction Hearing Aids I Kim S, et al.

Table 1. General characteristics of models currently produced by manufactures

\begin{tabular}{|c|c|c|c|c|c|c|c|c|}
\hline \multirow[b]{2}{*}{ Company } & \multirow[b]{2}{*}{ Name } & \multicolumn{3}{|c|}{ External device } & \multicolumn{4}{|c|}{ Internal device } \\
\hline & & Picture & $\begin{array}{l}\text { Release } \\
\text { year }\end{array}$ & $\begin{array}{l}\text { Channel/ } \\
\text { program }\end{array}$ & Name & Thickness & Type & MRI possibility \\
\hline Cochlear $^{\mathrm{TM}}$ & $\begin{array}{l}\text { Baha }^{\circledR} \\
5 \text { Sound } \\
\text { Processor }\end{array}$ & & 2015 & $17 / 4$ & $\begin{array}{l}\text { Baha }^{\circledR} \\
\text { Attract } \\
\text { system }\end{array}$ & Various & Attachment & $\begin{array}{l}\text { Yes } \\
\text { (up to } 1.5 \text { tesla) }\end{array}$ \\
\hline & & & & & $\begin{array}{l}\text { Baha }^{\circledR} \\
\text { Connect } \\
\text { system }\end{array}$ & Various & Abutment & \\
\hline MED-EL & $\begin{array}{l}\text { SAMBA Audio } \\
\text { Processor }\end{array}$ & & 2014 & $16 / 5$ & $\mathrm{BCl} 601$ & - & Attachment & $\begin{array}{l}\text { Yes } \\
\text { (up to } 1.5 \text { tesla) }\end{array}$ \\
\hline Sophono & $\begin{array}{l}\text { Sophono } \\
\text { Alpha } 2 \\
\text { MPO }^{\circledR M} \\
\text { Processor }\end{array}$ & & 2014 & $8 / 4$ & $\begin{array}{c}\text { Sophono }^{\circledR} \\
\text { Magnetic } \\
\text { implant }\end{array}$ & $2.6 \mathrm{~mm}$ & Attachment & $\begin{array}{l}\text { Yes } \\
\text { (up to } 3 \text { tesla) }\end{array}$ \\
\hline Oticon & Ponto 3 & $\S$ & 2009 & $15 / 4$ & $\begin{array}{l}\text { Photo BHX } \\
\text { implant }\end{array}$ & $3-4 \mathrm{~mm}$ & Abutment & \\
\hline
\end{tabular}

*Cochlear ${ }^{\mathrm{TM}}$ : http://red-dot.de/pd/online-exhibition/work/?code=26-00436-2015\&y=2015\&c=167\&a=0\&lang=en, ${ }^{\mathrm{T} M E D-E L: ~} \mathrm{http}: / /$ www.medel.com/int/samba-audio-processor, ‡Sophono: http://www.sophono.com/professionals/bone-conduction-hearing-device-product-details, §Oticon: https://www.oticonmedical.com/bone-conduction/solutions/systems/ponto-3

Baha ${ }^{\circledR} 5$ Sound Processor는 현재까지는 가장 많은 채널을 보유하고 있어 Sophono의 Sophono ${ }^{\circledR}$ Alpha $2 \mathrm{MPO}^{\mathrm{TM}}$ Processor와 비교 시 그 수가 2배를 넘는다. 한편, Cochlear ${ }^{\mathrm{TM}}$ 에 서 출시된 Baha ${ }^{\circledR}$ Connect System의 두께는 다양하게 있으 며 가장 얇은 두께는 약 $3 \mathrm{~mm}$ 이다. 같은 abutment 타입인 Oticon의 제품과 비교 시 크기 차이는 없다. Attachment 타 입은 Cochlear ${ }^{\mathrm{TM}}$, Sophono, Med-El에 있으며 삽입되는 자석 들 중 Sophono의 Sophono ${ }^{\circledR}$ Magnetic Implant가 MRI 검사 시 최대 3 tesla까지 허용 가능하여 attachment 타입이 있는 회 사들 중 가장 높은 것으로 분석된다.

\section{Candidacy}

이식형 골도 보청기는 일반적으로 귀 내부에 염증이 계속 발생되거나, 지속적인 이루, 선천성 외이 기형, 만성 화농성 중 이염, 만성 외이도염, 일측성 고도 난청, 일측성 혼합성 난청 이 있는 환자에게 혹은 보청기 착용이 실패한 환자에게 사용 을 고려하는 것으로 알려져 있다. ${ }^{6,11-14)}$ 만성 중이염의 경우, 이루가 없더라도 보청기 사용 시 되울림 현상이나 폐쇄 효과 로 인해 보청기 착용이 불가능한 경우가 있기 때문에 이식형 골도 보청기가 그 대안이 될 수 있다. ${ }^{6}$
이식형 골도 보청기는 구체적으로 순음 골전도 역치가 45 $\mathrm{dB}$ 이내인 환자들에게 권장되어 왔다. 그러나 최근에는 이식 물의 크기가 소형화되면서 골전도 역치가 $65 \mathrm{~dB}$ 이내의 환자 들까지도 이식형 골도 보청기를 착용할 수 있게 되었고, 소음 환경에서 소리를 분별할 수 있는 기능적 향상으로 그 적용 가 능성이 점차 넓어지고 있다. ${ }^{6}$ 이 대상자들은 전음성 난청이나 혼합성 난청을 가지고 있으며 전음성 난청은 기도골도역치 차 가 $10 \mathrm{~dB}$ 을 초과하며 외이나 중이의 기능에 이상이 있는 경우 를 말한다. 혼합성 난청이란 기도역치와 골도역치가 모두 비정 상이며 골도역치에 비해 기도역치가 더 나쁜 것[air-bone gap $(\mathrm{ABG})>10 \mathrm{~dB}]$ 을 일컫는다. ${ }^{15)}$

Niparko 등 ${ }^{16)}$ 의 연구에서 골전도의 역치가 $45 \mathrm{~dB}$ 이하 기 도전도역치가 $60 \mathrm{~dB}$ 의 감각신경성 난청을 가진 사람들에게 이식형 골도 보청기가 이득을 준다고 보고하였다. 감각신경 성 난청이란 기도역치와 골도역치가 모두 정상 범위보다 떨어 지며 기도골도역치가 $10 \mathrm{~dB}$ 이하 $(\mathrm{ABG} \leq 10 \mathrm{~dB})$ 로 나타난다. 그리고 내이 혹은 그 이후 청신경 및 중추신경계에 이상이 있는 것을 의미한다. ${ }^{15)}$ Mylanus 등 ${ }^{17)}$ 의 연구에 따르면 기도 전도 보청기와 이식형 골도 보청기 모두 착용 경험이 있는 환 자들 중 약 $81 \%$ 가 이식형 골도 보청기의 착용을 더 선호하였 
다. 이는 기도 전도 보청기를 사용하였을 때 폐쇄되었던 외이 도가 이식형 골도 보청기의 착용으로 귀의 염증 발생 정도가 확연히 감소되었기 때문으로 분석된다.

\section{Surgical procedures}

\section{Abutment surgery}

외이도에서 후방으로 50 55 mm 떨어진 위치에 외부장치 가 귓바퀴에 닿지 않도록 마크를 표시하고 지표의 전방 10 $\mathrm{mm}$ 에 절개선을 긋는다. 절개선은 20 30 mm로 hair line 방향에 맞춘다. 국소 마취를 하기 전 피하 주사 바늘, 클램프 및 자를 이용하여 조직 두께를 측정한다. 메스로 골막층 (periosteum)까지 절개하며 내부장치를 삽입할 위치를 확보 하기 위해 $6 \mathrm{~mm}$ 사각형으로 십자 절개를 한다. Burr를 이용 하여 삽입할 장소를 확대한 후, 뼈 표면에 도달할 때 확대 드 릴을 사용하여 최대 $0.5 \mathrm{~mm}$ 의 작은 받침대를 만든다. 확대 드릴은 카운터 싱크가 완료된 시점을 조기에 인식할 수 있도 록 설계한다. 고정물 자체를 두개골로 삽입하고 고정물 위에 미리 접합부를 끼운 후 뚫어놓은 구멍을 통해 삽입한다. 접 합부를 밖으로 돌출할 수 있도록 생검펀치(biopsy punch)를 이용하여 $5 \mathrm{~mm}$ 정도의 구멍을 뚫는다. 성인의 경우, 한 번에 고정물과 접합부를 삽입할 수 있다. ${ }^{5,18)}$ 그러나 아동은 두개골 의 두께가 $3 \mathrm{~mm}$ 이상이 되어야 수술이 가능하기에 어린 아 동의 수술은 각각 titanium과 titanium을 고정시킬 sleeper 를 삽입하는 경우로 나누어 진행한다. ${ }^{19)}$ 더 구체적인 수술 과 정은 $\mathrm{Han}$ 등의 연구와 Lee 등의 연구에서 확인할 수 있다. ${ }^{4,6}$

\section{Attachment surgery}

외이도의 후방 45 도 방향으로 외이도 입구에서 $6 \mathrm{~cm}$ 정도 떨어진 위치에 형판(template)을 사용하여 피부에 절개 위치 를 표시한다. 골막층(periosteum)까지 절개를 시행하고 골막 하 피판(subperiosteal flap)을 거상한다. 형판을 이용하여 2 개의 내부 자석을 이식할 위치를 표시한 후 $1 \mathrm{~mm}$ 지름의 burr 를 이용하여 $2 \mathrm{~mm}$ 깊이로 드릴링을 시행한다. 이식할 자석 의 위치를 다시 확인하고, 5 개의 나사를 이용하여 측두골에 내부 자석을 고정시킨 후 상처 봉합을 시행한다. 수술에 관한 구체적인 사항은 Rha 등 ${ }^{13)}$ 의 연구에 제시되어 있다.

Abutment의 수술 시간은 대략 25 분 정도로 짧게 걸리는 반면, attachment의 수술 시간은 약 1 시간 정도 소요된다. 회 복기간도 abutment, attachment 각각 2주와 4주 정도로 달 리 소요된다. ${ }^{7)}$

\section{Possible complications}

앞서 언급한 대로 이식형 골도 보청기는 attachment와 abutment 타입이 있다. Abutment 타입은 피부를 뚫은 titanium 을 통해 외부장치와 내부장치가 연결되기 때문에 피부 속에 자석을 삽입하는 attachment와는 나타나는 합병증이 다르다. Abutment 타입의 이식형 골도 보청기에서 대표적으로 나타 나는 합병증은 피부감염이다. Hol 등이의 연구에서 abutment 타입의 골도 보청기를 이식 수술한 27 명 중 12 명이 피부감염 을 보고하였다. 특히 그중 2명은 항상 피부감염이 있었고, 10 명은 수술 후 일년간 피부감염이 동반되었다고 보고하였다. Lustig 등 ${ }^{21}$ 의 연구에서는 abutment 타입의 이식형 골도 보 청기를 착용한 환자 40 명 중 1 명이 부착에 실패하였고, 3 명 은 이식 부분의 염증을 보고하였다. Hobson 등 ${ }^{14}$ 의 연구에 서는 지난 20년간(1984 2008년) 골도 보청기를 이식한 602 명의 환자들 중 $23.9 \%$ 가 합병증을 보고하였다. 주요 합병증 은 연조직 과성장(48명), 접합부 염증(31명), 접합부 이동(26 명), 트라우마(6명), 뼈 노출(5명), 두개골 이상감각(5명), 골유 착 실패(4명)였다. 이외에도 신경증, 지나친 피드백이 보고되었 다. 또한 이식 환자들 중 73명(12.1\%)은 피부와 연조직의 문 제, 염증 때문에 재수술을 받았다.

Attachment 타입의 이식형 골도 보청기의 보고된 합병증은 abutment 타입보다 횔씬 적었다. Siegert ${ }^{12}$ 의 연구에서 100 명 이상의 attachment 타입의 골도 보청기 이식 건수 중 보고 된 합병증은 거의 없었고, Sylvester 등 22$)$ 의 연구에서도 유사 하게 결과를 보고하였다. 이식을 받은 20명의 환자들 중 2 명 이 보고했던 피부 문제는 자석의 세기를 낮춘 후에 문제가 해결되었고, 다른 1 명도 피부홍반량 정도로 매우 미비했다. 그러나 Rhee 등")의 연구에서는 14명의 abutment 타입 이식 자 중 4명이 각각 비특이적 두통, 육아조직 발생, 켈로이드 발 생과 피부괴사를 보고하였고, 결국 추가 시술을 진행하였다.

\section{Audiological approach}

\section{Pre-operative examinations}

수술 전 환자의 청력을 측정하기 위해 순음청력검사를 실 시한다. 과거에는 일반적으로 순음 골전도 역치가 $45 \mathrm{~dB}$ 이 내인 환자들에게 권장되어 왔으나, 이식물의 크기가 소형화 되고 높은 출력을 얻을 수 있게 되면서 최근에는 골전도 역 치가 $65 \mathrm{~dB}$ 인 환자들까지 수술이 가능하게 되었다.) 편측성 난청 대상자를 선정하기 위한 조건으로는 좋은 쪽 귀의 청력 역치가 $35 \mathrm{~dB}$ 이하이며 어음인지도가 $80 \%$ 이상이고, 나쁜 쪽 귀의 청력이 $71 \mathrm{~dB}$ 이상이며 어음인지도가 $30 \%$ 이하이다. ${ }^{23)}$

수술을 시행하기 전 이식 대상자에게 골전도 소프트밴드를 
약 2주 정도 착용하도록 권장한다. 골전도 소프트밴드로 얻 는 청각적 이득은 수술을 통해 삽입한 골전도 보청기의 이득 보다 낮지만, 이식 후 골전도 보청기의 대략적 이득을 미리 확 인할 수 있기 때문에 수술에 대한 만족도를 예측할 수 있다. ${ }^{24}$

\section{Effective fitting strategy and fitting program}

이식형 골도 보청기의 fitting program은 기도 보청기의 fitting program과 매우 유사하다. Program을 처음 실시할 때 환자의 정보와 청력도를 입력한다. 기도 보청기에서는 기도 전도 역치를 위주로 입력한다면, 이식형 골도 보청기 조절을 위해서는 골도 전도 역치와 입력이 매우 중요하다.

골도 보청기를 착용한 상태에서 주파수별 역치 검사를 실 시한다. 이 청력도를 vibrogram이라고 한다. 그 다음, 기도 보 청기와 동일하게 program에서 설정된 fitting formula에 맞 춰 best fit의 그래프가 제시되고 필요 시 최대출력(maximum power output, MPO) 및 이득(gain)을 세부적으로 조절할 수 있다. 회사마다 구체적인 fitting 방법은 조금씩 다르지만, 다 양한 난청 형태에 따른 세분화된 fitting strategy는 아직 제공 되지 않고 있다.

\section{Post-operative examinations}

수술 후 환자의 청력 변화를 확인하기 위해 술전 검사와 동 일한 역치 평가를 실시한다. 또한 환자의 골도 보청기 착용 역 치를 포함하여 방향성 검사와 소음속 어음인지 검사를 실시 한다. 검사 도구로는 Hearing in Noise Test(HINT), Sound Azimuth Identification in Noise Test(SAINT), Bamford Kowal Bench-Speech In Noise test(BKB-SIN) 등이 있으며, 이식형 골도 보청기의 착용 이득을 평가하기 위해 대부분의 임상연구에서 HINT를 가장 많이 사용하였다. Linstorm 등하 의 연구에서는 이식형 골도 보청기 착용자를 대상으로 수술 후 1년 동안 HINT 검사를 실시하여 그 변화를 보고하였다.

객관적인 청각 검사 외에도 이식 후 주관적 청력 변화를 확 인하기 위해 설문 검사를 실시한다. 설문지의 종류로는 Hearing Handicap Inventory for Adults(HHIA), Speech, Spatial and Qualities of Hearing Scale(SSQ), Nijmegen, Abbreviated Profile of Hearing Aid Benefit(APHAB), single sided deafness questionnaire(SSD), Bern Benefit in SSD(BBSS), Glasgow Hearing Aid Benefit Profile(GHABP), International Outcomes Inventory for Hearing Aids(IOI-HA) 등이 있으며, 임상연구에서 가장 빈번하게 적용되었던 설문지는 $\mathrm{APHAB}$ 와 $\mathrm{GHABP}$ 로, 수술 전후의 설문 결과를 비교하여 주관적으 로 이득을 평가한다.

\section{Hearing benefits}

양이 혼합성 난청, 양이 전음성 난청, 편측성 혼합성 난청, 편측성 전음성 난청을 가진 환자들의 청력역치를 검사한 결 과, 스피커를 이용한 음장 검사가 실시되지 않아 착용 이득을 측정하지 못한 편측성 전음성 난청의 경우를 제외하고는, 모 든 환자에게서 이식형 골도 보청기 착용 후 어느 정도의 유의 미한 이득이 나타났다. 이식형 골도 보청기 중 abutment 타입 인 Cochlear의 Baha와 attachment 타입인 Sophono의 Sophono Alpha 2를 비교한 Shin 등ㄱㅇㅢ 연구에서 Baha와 Alpha 2 의 이득은 각각 $29.4 \mathrm{~dB}$ 과 $25.5 \mathrm{~dB}$ 이었다. 직접적으로 이식 된 내부장치와 연결하는 $\mathrm{Baha}$ 의 이득이 간접적으로 연결되 는 Alpha 2의 이득보다 약 $4 \mathrm{~dB}$ 정도 컸지만, 두 기기 모두 이식 후 유의미한 청력 이득을 보였다.

양이에 전음성 난청 또는 혼합성 난청이 있는 환자들의 어 음인지도 검사에서는 대체로 수술의 전후에 이득 차이가 거 의 없었다. ${ }^{17)}$ 그러나 Wazen 등 25 의 연구에서 이식형 골도 보 청기 수술을 한 환자의 어음인지도는 수술 전 가장 좋았던 결과와 비슷하거나 그보다 더 좋은 결과를 보였고, 어음명료 도 역시 증가하였다. $\mathrm{Hol}$ 등 $^{20)}$ 의 연구에서도 전음성 난청 또 는 혼합성 난청이 있는 환자들에게 어음인지도 검사를 실시 하였을 때 이식형 골도 보청기 착용 전후 유의미한 차이가 나타났다. CROS 보청기를 착용한 편측성 난청 환자의 경우, 안 좋은 귀에서 들려온 소리를 좋은 쪽 와우로 전달한다는 점에서 이식형 골도 보청기 착용 대상자의 방향성 검사 결과 처럼 이득이 없었으나, 소음속 어음인지도 검사 결과 두 기기 모두 착용 전보다 착용 후의 결과가 우수하였고, 특히 $\mathrm{CROS}$ 보청기보다 이식형 골도 보청기의 결과가 더 높게 나타났 다. ${ }^{16)}$ 이식형 골도 보청기 착용으로 인한 수술 후 평가 결과는 9개의 관련 논문들을 중심으로 분석 및 비교하였다(Table 2).

\section{고 찰}

이식형 골도 보청기는 1981년 측두엽에 부착하는 골도 보 청기 형태를 시작으로 현재의 자석을 이용한 간접적 연결 방 식의 이식형 골도 보청기까지 많은 발전을 이루었다. 이식형 골 도 보청기의 청각적 이득을 분석하기 위하여 이전 연구들에서 는 7개의 객관적 검사(sound localization, speech recognition test, BKB-SIN, pure-tone audiometry, HINT, SAINT, SIN) 와 9개의 주관적인 설문 검사(HHIA, SSQ, Nijmegen, $\mathrm{APHAB}$, $\mathrm{SSD}, \mathrm{BBSS}, \mathrm{GHABP}$, Quality of Life, IOI-HA)를 실시하 였다. 편측성 난청 환자들이 이식형 골도 보청기를 착용하여 도 방향성 검사에서는 이득을 얻은 경우가 매우 드물었다. ${ }^{28)}$ 즉, 방향성 기능은 심리음향적인 표현으로 양이에 들어오는 


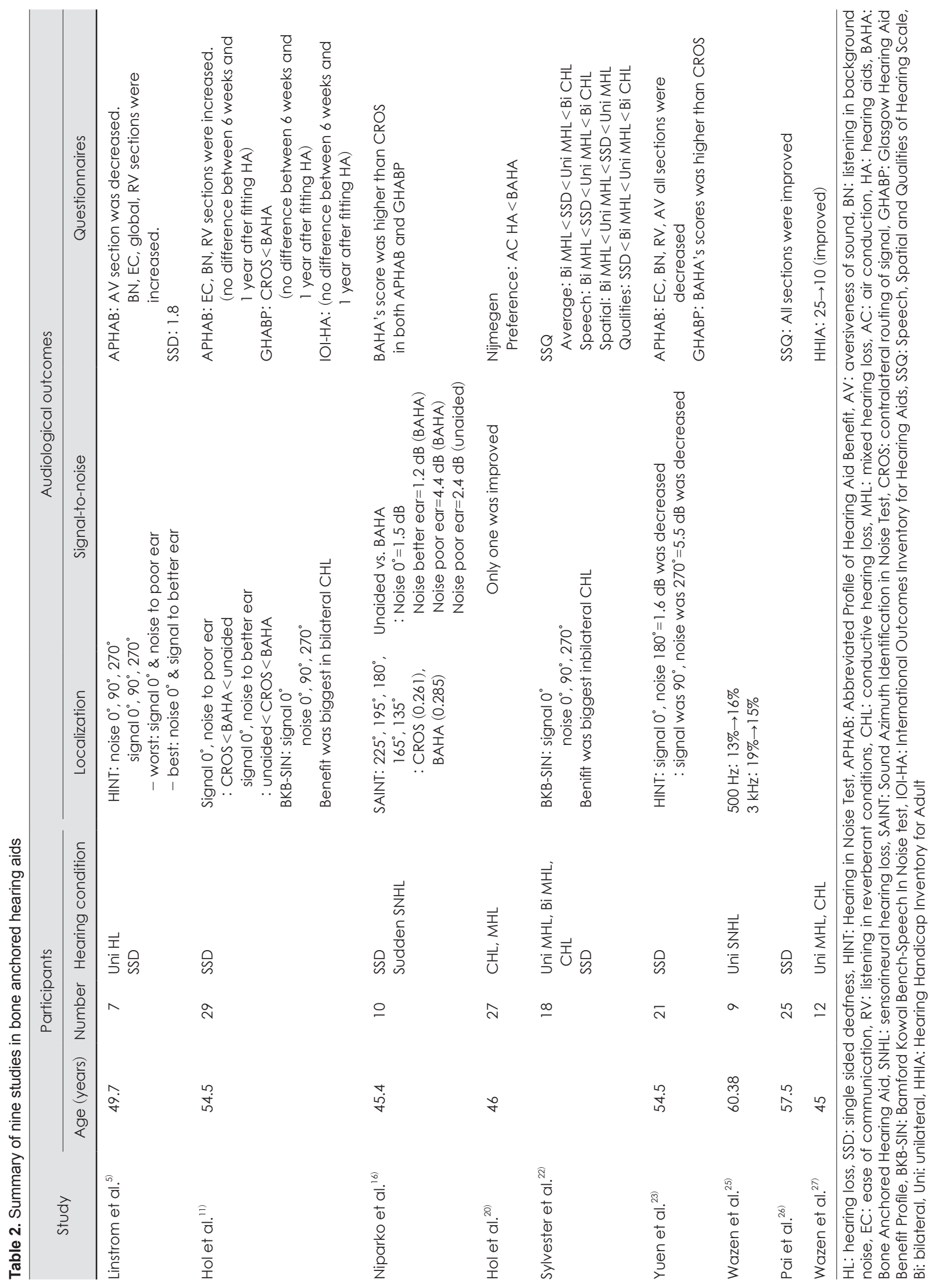


소리의 위상각, 시간, 강도의 차이를 동시에 인간의 말초 및 중추청각기관들에서 인지하고 통합되어 나타난다. ${ }^{29)}$ 즉, 이 식형 골도 보청기를 착용한 편측성 난청 환자는 이개에 의한 말초적 양이 효과를 회복할 수 없기 때문에 수술 후에도 방 향성 검사 시 유의미한 차이가 없던 것은 당연하다. 그러나 대부분의 연구에서는 소음하 어음인지도 검사에서 이식 전 후에 유의미한 결과 차이가 나타났다. 다시 말해, 소음 속에 서 어음인지의 증가된 이득은 말초청각기관보다는 중추청각 기관에서 더 크게 관여하기 때문에 이식형 골도 보청기 착용 환자들을 대상으로 착용기간에 따른 중추청각기관의 변화 및 청각적 이득을 확인할 필요가 있다.

대표적인 중추청각기관의 검사로는 low-pass filtered speech test, time-compressed speech test, dichotic test, Gaps-InNoise(GIN) 등이 있다. 몇몇 검사들은 음절을 양이에 불규 칙 혹은 무작위로 자극하기 때문에 비대칭적 난청이 있는 환자들에게는 실시되기 어렵다. 이러한 제한이 없으며 중추 청각기관의 temporal resolution(시간해상도) 능력을 확인하 는 목적으로 이식형 골도 보청기 착용자에게 적용할 수 있는 $\mathrm{GIN}$ 검사가 있다, $\mathrm{GIN}$ 검사는 $50 \mathrm{~dB} \mathrm{SL}$ 의 강도로 $6000 \mathrm{~ms}$ 동안 지속되는 백색잡음 사이에서 제시되는 여러 번의 다양 한 길이의 묵음 간격(e.g., 2 20 ms)을 탐지하는 역치를 확인 할 수 있어서, ${ }^{30)}$ 이식형 골도 보청기 착용 후 증가된 어음인지 도와 시간해상도의 의미 있는 관계를 밝힐 수 있을 것이다. 구체적으로, Schneider 등 ${ }^{31)}$ 의 연구에서 GIN 검사와 단어인 지도 간의 연관성이 높았고, 특히 GIN 검사 결과가 낮은(좋은) 환자의 경우 조용한 상황과 소음 상황에서 모두 어음인지도 간 유의미한 차이가 있었다. 따라서 이식형 골도 보청기 착용 자의 시간해상도 능력 및 백분율화된 소음하 어음인지도를 정확하게 측정한다면, 착용 후 중추청각기관의 이득 추이를 평가할 수 있고 주관적인 설문지의 만족도 향상 여부와 연계 시켜 보다 종합적인 청각적 이득을 도출해 낼 수 있을 것이다.

설문지는 수술 전과 후를 비교하였을 때 대부분의 항목에 서 긍정적인 결과가 나타났다. 즉, 대부분의 착용자는 이식형 골도 보청기에 대해 주관적인 착용에 대한 만족을 긍정적으 로 보고하였다. 그러나 IOI-HA 설문지 결과 분석 시, 이식형 골도 보청기의 만족도는 술 후 6 주와 1년의 차이는 거의 없 었고 ${ }^{20)}$ 이식형 골도 보청기 수술 후의 만족도는 시간에 따라 선형적으로 증가하지 않았다. 이는 착용자의 만족도가 초기 피팅에 따라 크게 좌우될 수 있음을 시사한다. 그럼에도 불 구하고 체계적으로 진행되는 보청기 피팅 혹은 인공와우의 맵핑과는 달리, 이식형 골도 보청기를 전문적으로 피팅하는 경우는 아직 드물다. 또한 저자들이 직접 시뮬레이션을 해 본 결과, 현재의 각 제조사에서 제공하는 프로그램은 주로
편 측성 난청인에게만 적합한 방식으로 개발되어 있고 양이 전음성 난청이나 혼합성 난청자를 위해 차별화된 공식은 내 재되지 않았다. 추후 이식형 골도 보청기 착용자의 난청 형태 와 정도에 따른 fitting strategy가 차별화되어 적용된다면, 그 결과에 따라 지금까지 대부분의 문헌에서 보고되지 않은 sound localization에서 유의미한 이득을 보일 것으로 감히 예상한다. 현재 골도 보청기 이식 수술은 의료보험법 제 9 조에 의해 지원을 받을 수 있다. 8세 이상 18세 이하의 양측성 선천성 이기형 환자, 청력검사 결과가 1) 양이의 기도-골도 청력의 차이가 각 $30 \mathrm{~dB}$ 이상인 전음성 난청, 양이의 기도-골도 청 력의 차이가 각 $30 \mathrm{~dB}$ 이상이면서, 2) 양이의 골도 청력이 각 $45 \mathrm{~dB}$ 이하인 혼합성 난청의 조건에 충족해야 한다. 1 회만 지원받을 수 있으며 골도 보청기는 국민건강보험법 제51조에 의한 보장구와 중복하여 요양급여하지 않는다. 이 조건에 해 당되는 경우, 수술료와 주된 치료재료 비용을 기준에 따라 본 인부담률을 $80 \%$ 만 적용한다. ${ }^{32}$ 임상가들은 이러한 보험 혜택 에 대해 숙지하고 이식형 골도 보청기 대상자와의 상담 시 청 각적인 이득뿐만 아니라 경제적인 혜택을 받을 수 있도록 정 보를 제공해야 하겠다.

\section{Acknowledgments}

This work was supported by the Ministry of Education of the Republic of Korea and the National Research Foundation of Korea (NRF-2015S1A3A2046760).

\section{REFERENCES}

1) Wilska A. A method of identification of hearing threshold amplitudes of the ear drum at various frequencies. Scandinavian Archives of Physiology 1935;72:161-5.

2) Rutschmann J. Magnetic audition-auditory stimulation by means of alternating magnetic fields acting on a permanent magnet fixed to the eardrum. IRE Trans Med Electron 1959;6(1):22-3.

3) Tjellström A, Håkansson B. The bone-anchored hearing aid. Design principles, indications, and long-term clinical results. Otolaryngol Clin North Am 1995;28(1):53-72.

4) Lee HK, Kim IS, Song MH, Lee WS. Experience of BAHA (Bone Anchored Hearing Aid) surgery. Korean J Otolaryngol-Head Neck Surg 2007;50(4):369-72.

5) Linstrom CJ, Silverman CA, Yu GP. Efficacy of the bone-anchored hearing aid for single-sided deafness. Laryngoscope 2009;119(4): 713-20.

6) Han KH, Kim H, Jang JH, Yoo JC, Kim YH, Lee JH, et al. Hearing rehabilitation with bone anchored hearing aid: experience in 14 patients. Korean J Otorhinolaryngol-Head Neck Surg 2010;53(12): $755-60$

7) Shin JW, Kim SH, Choi JY, Park HJ, Lee SC, Choi JS, et al. Surgical and audiologic comparison between sophono and bone-anchored hearing aids implantation. Clin Exp Otorhinolaryngol 2016;9(1):21-6.

8) Kim HJ. Introduction to middle ear implantable hearing devices. Audiol Speech Res 2016;12(Suppl 1):S33-7.

9) Rhee J, Chung J, Kim SH, Seo MW, Koo JW, Lee JH, et al. Subjective and audiologic results of Bone Anchored Hearing Aids (BAHA). Korean J Otorhinolaryngol-Head Neck Surg 2013;56(7):418-24.

10) Badran K, Bunstone D, Arya AK, Suryanarayanan R, Mackinnon N. 
Patient satisfaction with the bone-anchored hearing aid: a 14-year experience. Otol Neurotol 2006;27(5):659-66.

11) Hol MK, Bosman AJ, Snik AF, Mylanus EA, Cremers CW. Boneanchored hearing aids in unilateral inner ear deafness: an evaluation of audiometric and patient outcome measurements. Otol Neurotol 2005;26(5):999-1006.

12) Siegert R. Partially implantable bone conduction hearing aids without a percutaneous abutment (Otomag): technique and preliminary clinical results. Adv Otorhinolaryngol 2011;71:41-6.

13) Rha MS, Jeong SW, Seo YW, Moon IS. Hearing rehabilitation with Sophono ${ }^{\circledR}$ in patients with unilateral hearing loss after meningioma removal. Korean J Otorhinolaryngol-Head Neck Surg 2015;58(7): 514-9.

14) Hobson JC, Roper AJ, Andrew R, Rothera MP, Hill P, Green KM. Complications of bone-anchored hearing aid implantation. J Laryngol Otol 2010;124(2):132-6.

15) Goh EK, Kim LS, Kim CS, Kim JS, Kim HY, M IJ, et al. Practical manual of hearing tests. 2nd ed. Seoul; Hakjisa;2017. p.109-10.

16) Niparko JK, Cox KM, Lustig LR. Comparison of the bone anchored hearing aid implantable hearing device with contralateral routing of offside signal amplification in the rehabilitation of unilateral deafness. Otol Neurotol 2003;24(1):73-8.

17) Mylanus EA, van der Pouw KC, Snik AF, Cremers CW. Intraindividual comparison of the bone-anchored hearing aid and air-conduction hearing aids. Arch Otolaryngol Head Neck Surg 1998;124(3):271-6.

18) Cochlear $^{\mathrm{TM}}$. Cochlear ${ }^{\mathrm{TM}}$ Baha Systems SURGERY GUIDE. Cochlear ${ }^{\mathrm{TM}}$ [serial online] 2012, March (cited 2017 May 30). Available from: URL: http://www.cochlear.com/wps/wcm/connect/d953e307-0603-4ff88dac-ad4fee82f33c/BUN128+ISS2+AUG14+Baha+Surgery+Gui $\mathrm{de}+2 . p d f ? \mathrm{MOD}=\mathrm{AJPERES} \&$ CONVERT_TO $=$ url\&CACHEID $=$ d953e307-0603-4ff8-8dac-ad4fee82f33c.

19) McDermott AL, Williams J, Kuo M, Reid A, Proops D. The birmingham pediatric bone-anchored hearing aid program: a 15-year experience. Otol Neurotol 2009;30(2):178-83.

20) Hol MK, Snik AF, Mylanus EA, Cremers CW. Long-term results of bone-anchored hearing aid recipients who had previously used air-conduction hearing aids. Arch Otolaryngol Head Neck Surg 2005; 131(4):321-5.

21) Lustig LR, Arts HA, Brackmann DE, Francis HF, Molony T, Megerian
CA, et al. Hearing rehabilitation using the BAHA bone-anchored hearing aid: results in 40 patients. Otol Neurotol 2001;22(3):328-34.

22) Sylvester DC, Gardner R, Reilly PG, Rankin K, Raine CH. Audiologic and surgical outcomes of a novel, nonpercutaneous, bone conducting hearing implant. Otol Neurotol 2013;34(5):922-6.

23) Yuen HW, Bodmer D, Smilsky K, Nedzelski JM, Chen JM. Management of single-sided deafness with the bone-anchored hearing aid. Otolaryngol Head Neck Surg 2009;141(1):16-23.

24) Snik AF, Mylanus EA, Proops DW, Wolfaardt JF, Hodgetts WE, Somers T, et al. Consensus statements on the BAHA system: where do we stand at present? Ann Otol Rhinol Laryngol Suppl 2015;114 (12):2-12.

25) Wazen JJ, Ghossaini SN, Spitzer JB, Kuller M. Localization by unilateral BAHA users. Otolaryngol Head Neck Surg 2005;132(6): 928-32.

26) Pai I, Kelleher C, Nunn T, Pathak N, Jindal M, O'Connor AF, et al. Outcome of bone-anchored hearing aids for single-sided deafness: a prospective study. Acta Otolaryngol 2012;132(7):751-5.

27) Wazen JJ, Spitzer J, Ghossaini SN, Kacker A, Zschommler A. Results of the bone-anchored hearing aid in unilateral hearing loss. Laryngoscope 2001;111(6):955-8.

28) Kim G, Ju HM, Lee SH, Kim HS, Kwon JA, Seo YJ. Efficacy of boneanchored hearing aids in single-sided deafness: a systematic review. Otol Neurotol 2017;38(4):473-83.

29) Kamal SM, Robinson AD, Diaz RC. Cochlear implantation in singlesided deafness for enhancement of sound localization and speech perception. Curr Opin Otolaryngol Head Neck Surg 2012;20(5):393-7.

30) Sanches SG, Samelli AG, Nishiyama AK, Sanchez TG, Carvallo RM. GIN Test (Gaps-in-Noise) in normal listeners with and without tinnitus. Pro Fono 2010;22(3):257-62.

31) Schneider BA, Pichora-Fuller MK. Age-related changes in temporal processing: implications for speech perception. Seminars in hearing 2001;22(3):227-40.

32) National Health Insurance Act Koea. Treatment and surgical charge (nervous system, eye, cast, interventional, endoscopic). Judgement criteria inquiry. [cited 2017 Sep 1] Available from: http://m.hira.or. $\mathrm{kr} / \mathrm{mobile} / \mathrm{rf} / \mathrm{iac} / \mathrm{eva} /$ data.do?openDT $=20170630 \& \mathrm{seqNO}=6 \&$ matr $\mathrm{SeqNo}=22 \&$ sdate $=\&$ edate $=\& \mathrm{rnum}=47 \&$ category $=$. 


\section{정답 및 해설}

답 (5)

해 설 진단명: Thornwaldt cyst

Thornwaldt 낭은 발생과정에서 퇴화하지 않고 잔존하는 척삭조직(notochord)과 비인강 내배엽조직(nasopharyngeal endoderm)에서 기원한다. 대부분의 경우 20 30대에 진단되며 남녀의 성비는 동일한 것으로 보고되고 있다. 발생률은 일반적으로 3 7\% 정도로 보고되고 있으며 MRI 검사의 $0.2 \%$ 정도에서 우연히 발견된다. 대부분의 경우 증상이 없고 일부 환자에서 이물감 등을 호소할 수 있으며, 크기가 큰 경우 비 폐색을 유발할 수 있다. 감별해야 할 질환으로는 수막류 또는 뇌수막류가 있으며 CT 또는 MRI를 통해 두개 내와 교통이 있는지 확인해야 한다. 크기가 작은 경우 치료를 시행할 필요는 없으나 크기가 크거나 증상을 유발하는 경우 경비강 또는 경구강 내시경을 통해 쉽게 제거할 수 있다.

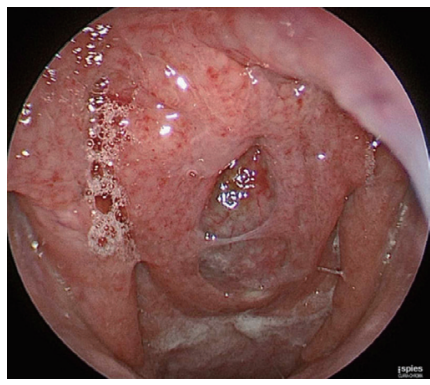

Preoperative endoscopic image

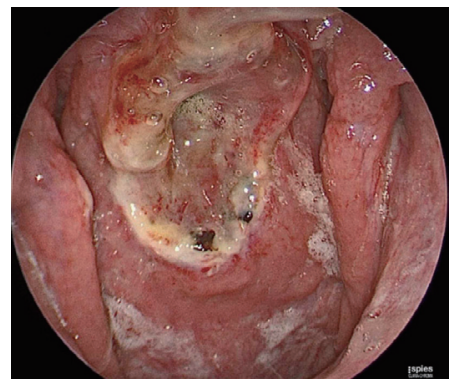

Postoperative 1 week endoscopic image

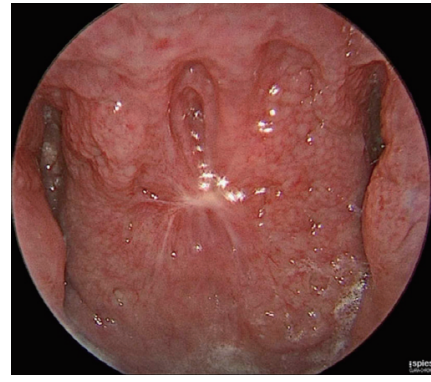

Postoperative 2 months endoscopic image 